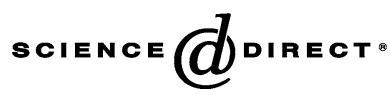

Global and Planetary Change 46 (2005) 187-198
GLOBAL AND PLANETARY CHANGE

www.elsevier.com/locate/gloplacha

\title{
Vegetation and climate variability during the Last Interglacial evidenced in the pollen record from Lake Baikal
}

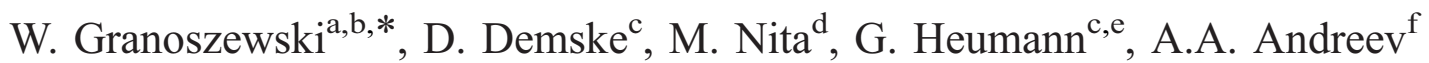 \\ ${ }^{a}$ Polish Geological Institute, Carpathian Branch, Skrzatow 1, 31-560 Krakow, Poland \\ ${ }^{\mathrm{b}}$ W. Szafer Institute of Botany, Polish Academy of Sciences, Lubicz 46, 31-560 Krakow, Poland \\ ${ }^{\mathrm{c}}$ Freie Universtät Berlin, Institut für Geologische Wissenschaften (Paläontologie), 12249 Berlin, Germany \\ ${ }^{\mathrm{d}}$ Faculty of Earth Sciences, University of Silesia, Bedzinska 60, 41-200 Sosnowiec, Poland \\ ${ }^{\mathrm{e}}$ Institut fuer Paläontologie, Friedrich-Wilhelms-Universität Bonn, 53115 Bonn, Germany \\ ${ }_{\mathrm{f}}^{\mathrm{f}}$ Alfred Wegener Institut für Polare und Marine Forschung, Telegrafenberg A43, 14473 Potsdam, Germany
}

Received 21 November 2003; received in revised form 29 June 2004; accepted 27 September 2004

\begin{abstract}
A pollen record from the core sediments collected in the northern part of Lake Baikal represents the latest stage of the Taz (Saale) Glaciation, Kazantsevo (Eemian) Interglacial (namely the Last Interglacial), and the earliest stage of the Zyryanka (Weichselian) Glaciation. According to the palaeomagnetic-based age model applied to the core, the Last Interglacial in the Lake Baikal record lasted about $10.6 \mathrm{ky}$ from 128 to $117.4 \mathrm{ky} \mathrm{BP}$, being more or less synchronous with the Marine Isotope Stage 5e. The reconstructed changes in the south Siberian vegetation and climate are summarised as follows: a major spread of shrub alder (Alnus fruticosa) and shrub birches (Betula sect. Nanae/Fruticosae) in the study area was a characteristic feature during the late glacial phase of the Taz Glaciation. Boreal trees e.g. spruce (Picea obovata) and birch (Betula sect. Albae) started to play an important role in the regional vegetation with the onset of the interglacial conditions. Optimal conditions for Abies sibirica-P. obovata taiga development occurred ca. $126.3 \mathrm{ky}$ BP. The maximum spread of birch forest-steppe communities took place at the low altitudes ca. 126.5-125.5 ky BP and Pinus sylvestris started to form forests in the northern Baikal area after ca. 124.4 ky BP. Re-expansion of the steppe communities, as well as shrubby alder and willow communities and the disappearance of forest vegetation occurred at about $117.4 \mathrm{ky} \mathrm{BP}$, suggesting the end of the interglacial succession. The changes in the pollen assemblages recorded in the sediments from northern Baikal point to a certain instability of the interglacial climate. Three phases of climate deterioration have been distinguished: 126-125.5, 121.5-120, and 119.5-119 ky BP. The penultimate cooling signal may be correlated with the cool oscillation recorded in European pollen records. However, such far distant correlation requires more careful investigation.
\end{abstract}

(C) 2004 Elsevier B.V. All rights reserved.

Keywords: Last interglacial; Lake Baikal; South Siberia; pollen; vegetation and climate history

\footnotetext{
* Corresponding author. Polish Geological Institute, Carpathian Branch, Skrzatow 1, 31-560 Krakow, Poland.

E-mail address: Wojciech.Granoszewski@pgi.gov.pl (W. Granoszewski).
} 


\section{Introduction}

Studies of bottom sediments of Lake Baikal and of organic sediments from its catchment flourished in the 1990s. Owing to the great age of the lake, its sediments are a source of unique data, potentially recording changes in vegetation and climate over the past 25 million years (Hutchinson et al., 1992). This present study focuses on the pollen record from the Lake Baikal region, representing the Last Interglacial, which is known as Kazantsevo in Siberia (or the Mikulino in the European Russia and the Eemian in West Europe).

Vegetation and climatic changes during the Kazantsevo Interglacial have been extensively studied in Western Siberia. Palaeobotanical data show distinct vegetation zonation throughout the climatic optimum from birch-pine forests with a mixture of Abies, Tilia, Ulmus, and Quercus in the south of the West Siberian Plain, through to Scots pine-Siberian pine forests with Picea and Abies in the middle part of West Siberia, to birch forests with a mixture of Picea in the north (Arkhipov and Volkova, 1994; Volkova and Bakhareva, 1995). During the Mikulino Interglacial climatic optimum, the central Russian plain in the European part of Russia was covered with broad-leaved (Quercus, Ulmus, Corylus, Tilia, Carpinus) and coniferous/ broad-leaved forests with Picea and Pinus sylvestris (Grichuk, 1984). The Eemian vegetation succession is fairly well characterised and has parallels across western parts of Europe (Turner, 2000). The pattern of appearance and culmination of tree pollen during the Eemian shows one of the most distinctive interglacial successions (Menke and Tynni, 1984). The beginning of this interglacial is marked by the development of birch-pine forests, which were replaced by broad-leaved forest communities of Ulmus, Quercus and Corylus as a result of improving climate conditions. The influx of Corylus is followed by Taxus and Tilia. Meanwhile in the younger part of the climatic optimum, Carpinus was the main element of forest communities, followed by Abies and Picea. The development of pine forests ends the succession of this interglacial. Hitherto, the Late Pleistocene flora of the Kazantsevo Interglacial has been recorded at only a few sites in South Siberia (Belova, 1985) and to date there has been no continuous pollen record of this age from Lake Baikal.

Modern climate in the Lake Baikal region of Siberia is strongly continental. Mean January temperatures vary from -20 to $-34{ }^{\circ} \mathrm{C}$ while those of July from +12.8 to $+20.4{ }^{\circ} \mathrm{C}$. The highest precipitation (700-800 $\mathrm{mm}$ per year) is noted on the northern slopes of the Pribaikal region while the lowest levels (ca. $250 \mathrm{~mm}$ per year) are recorded in some areas east of Lake Baikal (Peshkova, 1985; Chlachula, 2001). The vegetation is dominated by coniferous forest of taiga type growing on the slopes of the mountain range surrounding Lake Baikal. Composition of these forest communities depends on elevation above the sea level and the slope exposure. More damp, western slopes are covered by Pinus sibirica, Abies, and Picea taiga whereas on dryer east-facing slopes Pinus sylvestris and Larix forests are established (Bezrukova et al., 1999). Deciduous trees (mainly Betula and Populus) usually form secondary forests, which appear, for example, after taiga fires. Steppe communities occur mainly on the eastern slopes of the Baikal Range where very little moisture is available. Above the upper forest limit Pinus pumila and Alnus fruticosa grow in the subalpine belt (Tyulina, 1976).

Studies of oxygen isotopes from Greenland ice cores initiated discussion of the stability and climate variability of the Last Interglacial (GRIP members, 1993). A number of studies of lake sediments in Europe have provided evidence of climatic oscillation during the Eemian. Oxygen isotope records from Greenland ice cores, and pollen-based climate reconstructions performed on the annually laminated records from Bispingen/Luhe (Müller, 1974; Field et al., 1994) and on several other pollen records from France, Poland and Germany (de Beaulieu and Reille, 1992; Thouveny et al., 1994; Cheddadi et al., 1998; Klotz et al., 2003) pointed to a fairly pronounced midEemian cooling event. On the other hand, Kühl and Litt (2003) using another statistical approach to reconstruct palaeoclimate from west European pollen data suggested rather stable temperatures through the Eemian.

On the basis of biogenic silica and diatom abundance in sediments of Lake Baikal, Karabanov et al. (2000) also reconstructed a mid-Eemian cooling and suggested strong climatic teleconnections between the 
North Atlantic and continental Asia during the Last Interglacial. However, there were no previous attempts to identify climate oscillations in the sensitive area of South Siberia during the Last Interglacial based on pollen data from Lake Baikal.

This paper presents the first continuous pollen record of the Last Interglacial from core CON01-603-2 from the Northern Basin of Lake Baikal and, reconstruction of interglacial vegetation history on the basis of this pollen sequence.

\section{Material and methods}

The studied core CON01-603-2 $\left(53^{\circ} 57^{\prime} \mathrm{N}\right.$, $\left.108^{\circ} 54^{\prime} \mathrm{E}\right)$ was recovered from the Continent site, Northern Basin from a water depth of 386 m (Fig. 1) (see Charlet et al., 2005-this volume). The analysed sequence $(725.5-608 \mathrm{~cm})$ consists of mainly of biogenic, diatomaceous sediments, although the upper part of the sequence between ca. 611-608 $\mathrm{cm}$ contains more silt particles and less diatoms than

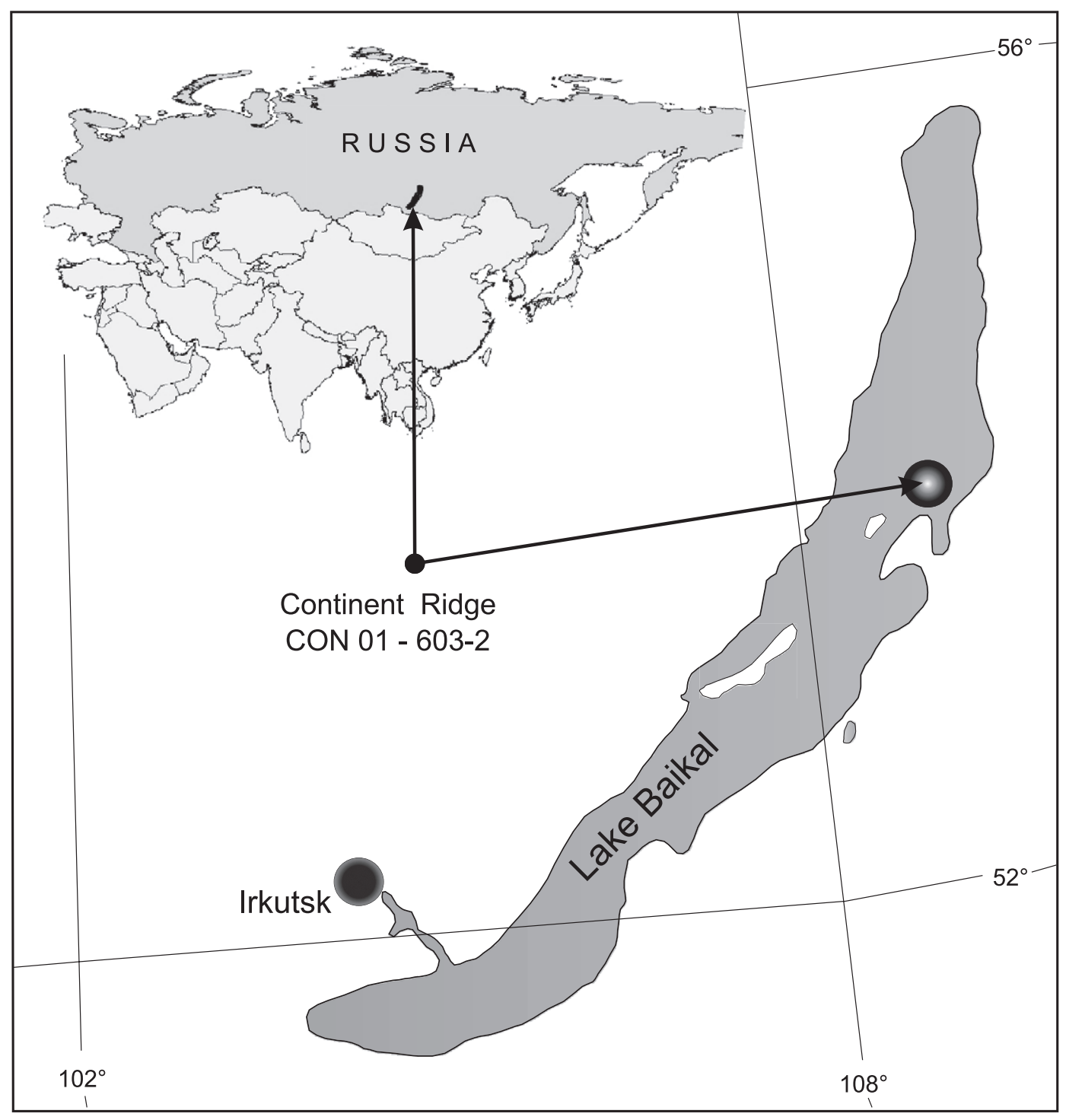

Fig. 1. Map of Lake Baikal showing the coring site, CON01-603-2. 
the lower part of the sequence. From a depth of 690 $\mathrm{cm}$ upwards the sediments are finely and coarsely laminated.

Based on a standard technique for processing palynological samples, silicates were removed from the sediment by treatment with $40 \% \mathrm{HF}$ for 3 days and with 50\% HF for 1 day. Following Erdtman's acetolysis (Faegri and Iversen, 1989) sediment samples were sieved through $7-\mu \mathrm{m}$ meshes in an ultrasonic water bath (Cwynar et al., 1979). To assess absolute pollen and spore concentrations in the sediment, samples of known volume (2.5-3.5 $\mathrm{cm}^{3}$ ) were taken and two tablets of marker (Lycopodium spores) added to each sample (Stockmarr, 1971).

The basic calculation sum consists of tree, shrub and terrestrial herb pollen, and counts range between 500 and 1000 grains for the interglacial part of the section and between 200 and 500 grains for the Early Glacial. Others taxa, such as Pteridophytes, mosses and algae are calculated in relation to the basic sum enlarged with respective taxa group.

The pollen sequence was subdivided into Local Pollen Assemblages Zones (LPAZ) and subzones (LPASZ) using constrained incremental sum of squares clustering (CONISS) (Grimm, 1987). The pollen zones are prefixed with $\mathrm{CK}$ (Continent Kazantsevo) and are numbered from the core base upwards (Fig. 2).

The chronology of core CON01-603-2 is based on the paleomagnetic data tuned to a reference curve (Demory et al., 2005- this volume) from ODP Site 984 (Channell, 1999). The age model applied suggests that the studied sediments accumulated between $\sim 130-115$ ky BP. Except for the topmost and the very bottom layers, this interval corresponds to the highest total sporomorph concentration values.

In order to trace climatic changes in the studied pollen record and to perform regional and continental-scale comparison, we attributed pollen taxa to the several characteristic plant communities with well-defined climatic requirements. Previous attempts to group pollen taxa recorded in the Late Quaternary sediments from northern Eurasia using plant functional types and biome classification are presented in Tarasov et al. (1998, 2000), while a more detailed vegetation classification for the Baikal region is published by Tyulina (1976) and Belov
(1972). Fig. 3 presents the dynamics of the basic plant formations of southern Siberia. Dry vegetation types are represented by the following pollen sums: S1 (steppe), S2 (birch forest-steppe), S3 (Pinus sylvestris and Larix taiga). The relatively moist vegetation types are represented by the following sums: S4 (Picea obovata, Abies sibirica, and Pinus sibirica taiga), S5 (subalpine shrubs), S6 (shrubs of moist sites), and S7 (boreo-alpine vegetation). Proposed climatic and vegetation indices capture changes in both climate and vegetation semiquantitatively. Thus, general trends in precipitation and temperature are expressed by the moisture index $I_{\mathrm{m}}$, which is the ratio of $\mathrm{S} 1+\mathrm{S} 2+\mathrm{S} 3$ to $\mathrm{S} 4+\mathrm{S} 5+\mathrm{S} 6$ pollen sums and by the temperature index $I_{\mathrm{t}}$ calculated as ratio of $\mathrm{S} 2+\mathrm{S} 3+\mathrm{S} 4+\mathrm{S} 6$ to S5+S7.

The order of changes in plant formations and the curves of the abovementioned indices, together with the age model, allow vegetation/climatic phases to be inferred and dated.

\section{Results and interpretation}

\subsection{Pollen and spores preservation and identification}

With the exception of the uppermost and lowermost section, the total pollen and spore concentration was very high (Fig. 2). The sediments below $725.5 \mathrm{~cm}$ depth contains practically no pollen. Pollen preservation was reasonably good or very good, but the number of corroded grains increased in the upper part of the section. Bisaccate pollen grains (e.g. Pinus, Picea and Abies) were very often broken and fragmented.

In the study area the Pinus sibirica-type comprises pollen of two pine species i.e. P. sibirica and Pinus pumila since their pollen grains are morphologically very similar. However, these two pine species have different ecological requirements and are associated with different plant communities and elevation belts. $P$. sibirica is a tree growing in taiga forest while $P$. pumila is a shrub and thrives mainly above the upper forest limit. Taking into account much wider distribution of $P$. sibirica in the Baikal region during the Holocene and today we assume that pollen of $P$. sibirica-type in the interglacial 


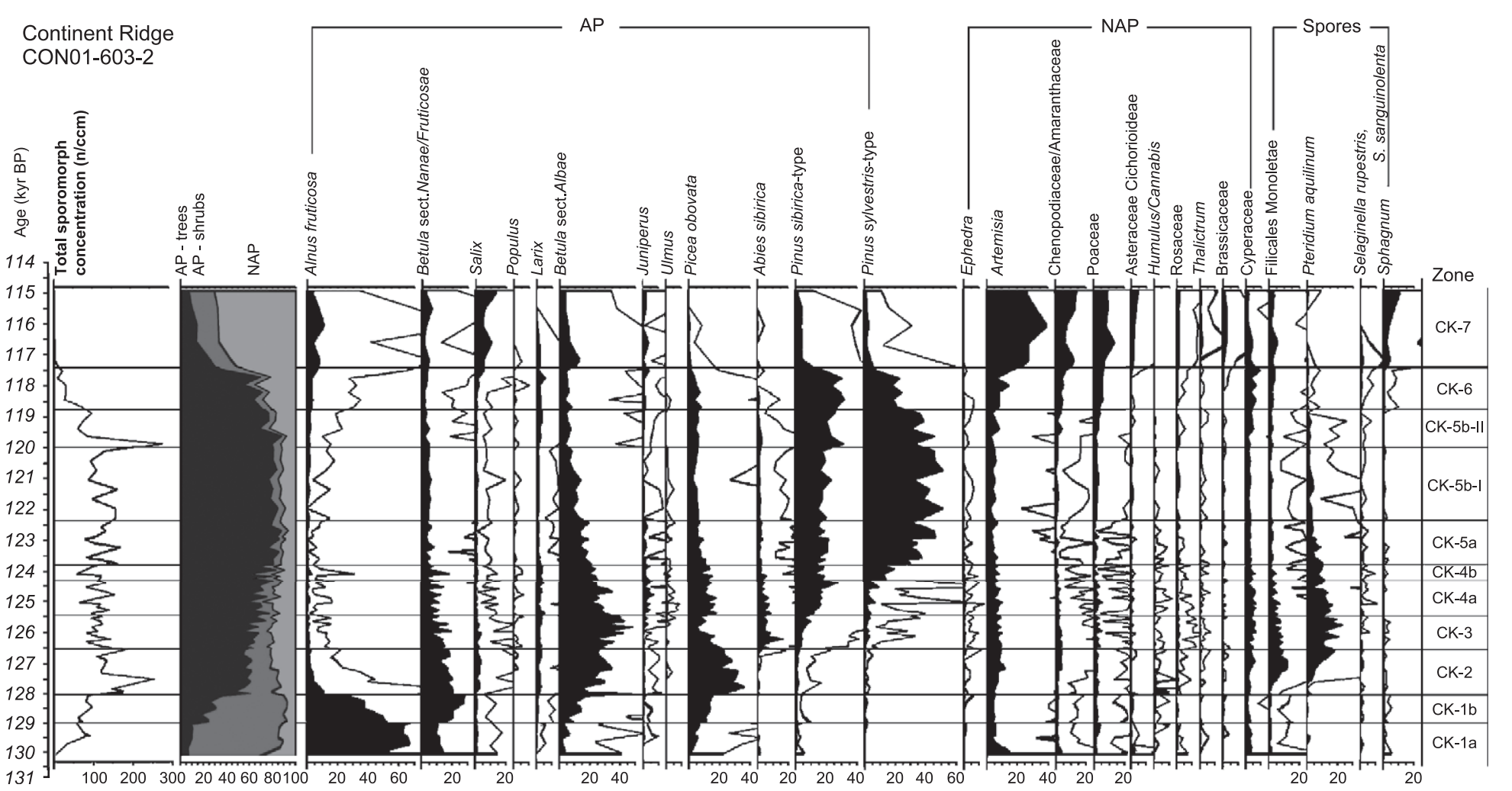

Fig. 2. Pollen diagram showing percentages of selected taxa and total sporomorph concentration from the core CON01-603-2 plotted against time scale. Right-hand column-local pollen zones and subzones. (Data available at: 10.1594/GFZ/ICDP/CON/2004.) 


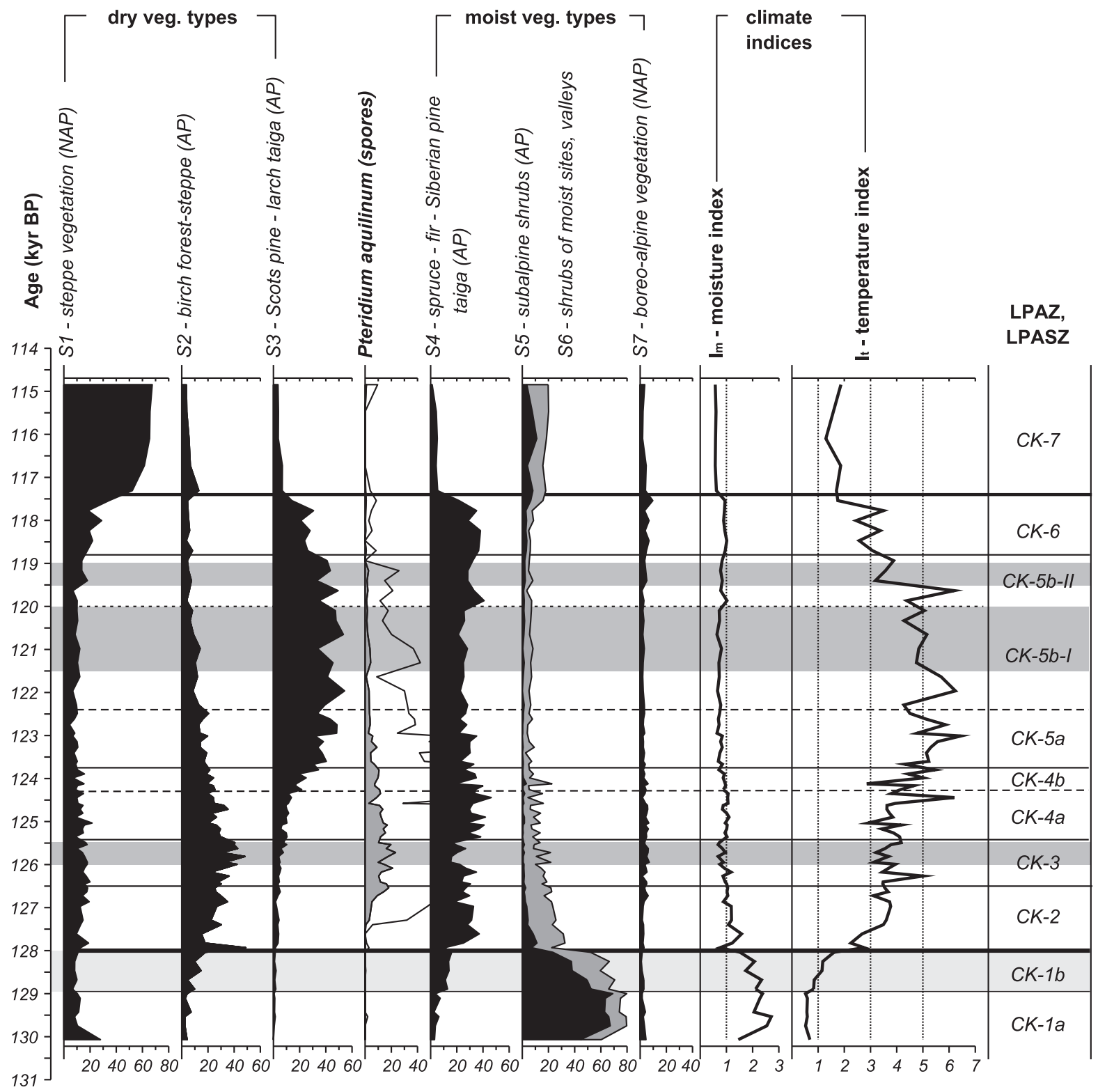

Fig. 3. Palaeoclimatic interpretation based on changes of major vegetation types (S1-S7). $I_{\mathrm{m}}$-ratio of $\mathrm{S} 1+\mathrm{S} 2+\mathrm{S} 3$ to $\mathrm{S} 4+\mathrm{S} 5+\mathrm{S} 6, I_{\mathrm{t}}$-ratio of $\mathrm{S} 2+\mathrm{S} 3+\mathrm{S} 4+\mathrm{S} 6$ to S5+S7. Grey bands highlights the time intervals of climate deterioration. For details see text. (Data available at: 10.1594/GFZ/ $\mathrm{ICDP} / \mathrm{CON} / 2004)$

pollen spectra were mainly contributed by $P$. sibirica trees. The proportion of $P$. pumila pollen might be greater in the pollen spectra dated to the very beginning of the interglacial and to the beginning of the last glaciation.
Redeposited pollen and spores were recorded throughout the whole sequence in very low amounts. Some taxa, such as Osmunda spores and Pterocarya and Podocarpus pollen must be reworked from the older (Tertiary) coastal deposits, while others (Cor- 
ylus, Carpinus, Quercus) most probably originate from long distance transport.

\subsection{Pollen stratigraphy and vegetation development}

The study pollen sequence spans the time period between ca. 130 and $114.8 \mathrm{ky} \mathrm{BP}$ and represents the late glacial leading into Termination II, the fully developed interglacial succession and the beginning of the early Zyryanka (Weichselian) glaciation in the Baikal area. The pollen diagram (Fig. 2) has been divided into seven Local Pollen Assemblage Zones (LPAZ) and several subzones (LPASZ).

\subsubsection{Late glacial of the Taz (Saalian) glaciation}

CK-1 LPAZ (725.50-715.75 cm, ca. 130-128 ky $\mathrm{BP}$ ) is noted for absolute maximum of Alnus fruticosa pollen 70\% (CK-1a), rise in Betula sect. Nanae/Fruticosae pollen percentages up to $28 \%$ and increase an in Picea obovata abundance up to $16 \%$ (CK-1b).

In the lowermost part of the zone fairly high values of Artemisia and other herbs (Chenopodiaceae/Amaranthaceae, Asteraceae/Cichoroidae, Thalictrum) were recorded, suggesting an existence of steppe plant communities around the Northern Basin. After the partial retreat of steppe communities, a great expansion of Alnus fruticosa thickets took place, and it became the dominant plant formation (CK-1a) while distribution of shrub tundra communities with Betula nana (Betula sect. Nanae/Fruticosae) and dwarf species of Salix became less pronounced.

The changes in the pollen assemblages recorded in $\mathrm{CK}-1 \mathrm{~b}$ are of a transitional nature, and reflect the early development of forest communities in the region. Warming of the late glacial climate caused the spread of Picea obovata and Betula (Betula sect. Albae) and the recession of Alnus fruticosa thickets. At the same time damp habitats were most probably overgrown by tundra vegetation with Betula nana.

\subsubsection{The Kazantsevo (Eemian) interglacial}

In CK-2 LPAZ (715.75-706.50 cm, 128-126.5 ky BP) the maximum of Picea obovata pollen $(36 \%)$ is recorded, suggesting that spruce taiga became the dominating forest formation. The maximum spread of the spruce-dominated forests occurred between 127.8-126.9 ky BP. The very high pollen values of $P$. obovata could indicate the formation of the upper forest belt in the mountains. A small increase in Pinus sibirica-type pollen possibly reflects the presence of shrub communities with Pinus pumila. Further expansion of trees in the northern Baikal region became possible under the relatively warm and wet climate at the beginning of the interglacial. At the same time, birch foreststeppe with Larix gradually spread in the area at lower elevations. The rapid expansion of Pteridium aquilinum ca. 127.4 ky BP was most probably associated with these communities.

CK-3 LPAZ (706.50-694.75 cm, 126.5-125.4 ky BP) is noted for maximum abundances of Abies sibirica (17\%) and Betula sect. Albae (48\%) pollen. Changes in the forest communities were characterised by a rapid spread of $A$. sibirica, a slightly later expansion of Pinus sibirica and the retreat of Picea obovata. After the Abies peak ( 126.3 ky BP) the clear retreat of taiga took place and the simultaneous expansion of birch-larch forest-steppe with the occurrence of Artemisia, Chenopodiaceae/Amaranthaceae, Cyperaceae, Ephedra and Juniperus. Various taxa belonging to the Rosaceae family were abundant in this pollen zone, as well as spores of Selaginella sanguinulenta, which indicate the development of steppe communities on the mountain slopes and rocky soils. In more humid habitats in the mountains, shrub tundra communities with $B$. nana persisted.

In CK-4 LPAZ (694.75-677.50 cm, 125.4-123.75 ky BP) increase in Pinus sibirica-type up to $27 \%$ (CK-4a) and in Pinus sylvestris-type pollen up to $20 \%$ (CK-4b) is recorded, suggesting the re-expansion of taiga. In the period from about 125.4-124.4 ky BP (CK-4a LPASZ) taiga communities were stable and consisted mainly of Picea obovata, Abies sibirica and P. sibirica. During this period P. sylvestris forests started to expand in the region, and were likely to have occupied drier habitats at lower altitudes. Simultaneously, the wide spread of Juniperus is also observed. With the gradual recession of birch foreststeppe communities, the vegetation in the lower mountain belt changed into taiga communities with P. sylvestris and Larix. This process continued during formation of CK-4b LPASZ (after ca. 124.4 ky BP).

CK-5 LPAZ (677.50-634.25 cm, 123.75-118.8 ky $\mathrm{BP})$ is characterised by maximum abundances of 
Pinus sylvestris-type pollen (52\%), suggesting rapid expansion of $P$. sylvestris and dominance of the pine forests in the region. Scots pine was the main tree species in the area at this time, forming most probably together with Larix taiga communities at lower altitudes. At higher elevations, northern mountain slopes were covered by Siberian pine-spruce-fir taiga perhaps with some $P$. sylvestris as well.

In CK-6 L PAZ (634.25-619.25 cm, 118.8-117.4) maximum of Pinus sibirica-type pollen (33\%) is accompanied by a decrease in Pinus sylvestris-type pollen percentages.

The transformation of vegetation in the north Baikal region at that time is characterised by impoverishment of Siberian pine-spruce-fir taiga communities at ca. $118 \mathrm{ky} \mathrm{BP}$ and most probably their retreat from the area at ca. 117.5 ky BP. Low elevated dry habitats were occupied by Scots pinelarch taiga and steppe communities. At higher elevations, boreo-alpine and subalpine communities became more important, as shown by an increase in the pollen percentages of the relevant vegetation types (Fig. 3). These changes in vegetation cover indicate a down slope shift of the vegetation belts, which implies onset of significantly moist and cooler climate.

\subsubsection{Early glacial of the Zyryanka (Weichselian) glaciation}

CK-7 L PAZ (619.25-608.00 cm, 117.4-114.8 ky $\mathrm{BP})$ is noted for very high values of NAP $(72 \%)$, and a slight increase in the abundances of Alnus fruticosa, Salix and Betula sect. Nanae/Fruticosae pollen, suggesting the wide-spread development of open vegetation types. A cooler climate at the transition to glacial conditions led to the disappearance of forest in the Northern Baikal Region. Steppe communities with Artemisia, Chenopodiaceae/Amaranthaceae, Poaceae, and others underwent a large expansion to become the dominant plant communities. Single birch and larch trees perhaps could survive only in the protected habitats. Habitats with better moisture availability likely existed in the mountains and in the river valleys, and were overgrown by $A$. fruticosa thickets and tundra communities with Betula nana and dwarf species of Salix. High values of Sphagnum spores in the pollen spectra contribute to the evidence for the spread of tundra associations in the area.

\section{Discussion}

\subsection{The age and time boundaries of the last interglacial}

The Eemian Interglacial of Europe, defined on the basis of changes in the development of forest communities, lasted longest in the south of the continent, about $15.5 \mathrm{ky}$, (Tzedakis et al., 2002, 2003). Studies of the annually laminated Eemian sediments from northern Germany suggested that the Last Interglacial continued about 11 ky (Müller, 1974). According to Turner (2002), the Last Interglacial in the area north of the Alps and Pyrenees lasted no longer than $13 \mathrm{ky}$.

According to the age model applied to the core CON01-603-2, the interglacial vegetation succession in the Lake Baikal region lasted from $\sim 128 \mathrm{ky}$ BP (CK-1/CK-2 LPAZ) to $117,4 \mathrm{ky}$ BP (CK-6/CK-7 LPAZ) i.e. $10.6 \mathrm{ky}$. The same age boundaries are also inferred from the diatom assemblages (Rioual et al., 2005-this volume). Prokopenko et al. (2002) suggest a slightly different duration of this warm stage in the Lake Baikal region: their age model is based on orbitally tuned record of biogenic silica, and these authors dated the Kazantsevo Interglacial from 127 to 115 ky BP, i.e. about $12 \mathrm{ky}$.

In our record the glacial/interglacial boundary (i.e. Termination II) is marked by a decline in Alnus fruticosa pollen and an increase in Picea obovata, and Betula sect. Albae pollen percentages. These changes take place at the transition from the pollen zone CK-1 to pollen zone CK-2.

In order to compare vegetation and climate changes reconstructed from the Baikal record with other interglacial sequences, chronological control and stratigraphic definition is necessary. In Europe, the glacial/interglacial boundary is traditionally drawn at the level from which arboreal pollen become a dominant component in the pollen assemblages (Turner and West, 1968; Tzedakis et al., 2003). According to the latter authors the beginning of the Eemian Interglacial is also defined by an increase in the AP concentrations to above 200,000 grains $/ \mathrm{cm}^{3}$.

The criteria used in Europe are not, however, fully justified in south Siberia. The glacial/interglacial boundary in our record is drawn at the level, where 
shrub (ca. 40\%) and tree pollen (ca. 40\%) values are much greater than those of NAP. The first increase in the proportions of Picea abies and Larix, noted in subzone CK-1a, is interpreted as a precursor of forthcoming changes belonging to the late glacial. According to Bezrukova and Letunova (2001) the increase in the pollen of both these trees is a good indicator of the closing phase of glacial stages in south Siberia. Changes in subzone CK-1b (129-128 ky BP) have a transitional character and a low proportion of tree pollen (less than 30\%). Thus, it was considered as final part of the Taz Glaciation.

The interglacial/glacial boundary, corresponding to the boundary between pollen zones CK-6 and CK-7, was determined according to the criteria used in Europe-increase in the NAP percentages to above $50 \%$. Glacial spectra are dominated by high values of Artemisia, Poaceae, Chenopodiaceae/Amaranthaceae, Brassicaceae, and Asteraceae Cichorioidae, and by pollen of Alnus fruticosa, Salix, and Juniperus. At the same time a drastic fall in Pinus and Picea pollen percentages is observed.

\subsection{Palaeoclimatic interpretation of the pollen record}

\subsubsection{Penultimate late glacial/interglacial high- amplitude climate variation}

In the analysed CON01-603-2 core only climaticvegetation changes of the terminal part of the Taz Glaciation are recorded. Retreat of steppe vegetation (S1) and spread of subalpine communities represented mainly by Alnus fruticosa (S5) between 130.1 and $129.5 \mathrm{ky}$ BP point to a cold climate and to a steady increase in humidity (Fig. 3). Since ca. 129.5 ky BP the moisture index $I_{\mathrm{m}}$ shows a trend towards a slightly drier climate. Warmer thermal conditions, suggested by increased values of the temperature index $\left(I_{\mathrm{t}}\right)$ started only ca. 129 ky BP. Retreating of A. fruticosa thickets and spread of Picea obovata and Betula forests reflected the abovementioned changes in the regional climate. The climate of the latest phase of the Taz glaciation was still cold and wet.

\subsubsection{Thermal optimum phases}

The climate of the initial part of the interglacial gradually became warmer. The increase in precipitation at around 127.8-127.4 ky BP, indicated by an increase in the moisture index, permitted a strong expansion of Picea obovata. The next shift towards a gradual reduction in precipitation persisted till 126.4 ky BP. In the vegetation of the northern region of Lake Baikal, these changes in climate were accompanied by the broad spread of birch forest-steppe communities (S2). Around $126.4 \mathrm{ky}$ BP there was a very clear, though short-lived rise of temperature and moisture, and registering in the pollen assemblages by a rapid increase in Abies pollen percentages.

The favourable climatic conditions to expansion of fir-spruce taiga forest were, however, disrupted as a result of a short-lived climatic oscillation between 126 and $125.5 \mathrm{ky}$ BP. During this interval a distinct shift towards lower temperatures appears in the temperature index curve, and on the moisture index curve appears a shift towards dryer conditions. Yet despite the fact that climatic conditions improved after 125.5 ky BP, as evidenced by an increased importance of Abies sibirica and Picea obovata in the regional vegetation, these trees did not regain their previous spread. As a result of the mentioned climatic oscillation the taiga communities were partly transformed and Pinus sibirica gradually became a more common component of these forests.

Between 123.7 and $121.5 \mathrm{ky} \mathrm{BP}$, the climate was probably as warm as in the period of the maximum distribution of Abies sibirica, but substantially drier. The latter climatic conditions were conducive to the expansion of Scots pine taiga.

As a result of drop in temperatures between 121.5 and $120.75 \mathrm{ky}$ BP the development of the forest communities was clearly influenced by a partial retreat of Pinus sylvestris. Forest-steppe with Pteridium aquilinum occupied a slightly larger area, as did steppe vegetation. In Siberian pine-fir-spruce taiga communities, the proportion of Abies sibirica and Picea obovata decreased somewhat. Further changes were associated with a retreat of Pinus sibirica, which took place between 120.75-120 ky BP. These changes reflect the next climatic oscillation (121.5-120 ky BP). The temperature index points to cooler climatic conditions than occurred before and after the oscillation. It must, however, be stressed that this oscillation, despite the cooler climatic conditions, was still a relatively warm and dry interval according to the pollen evidence.

Warmer and slightly wetter climatic conditions between 120 and $119.5 \mathrm{ky}$ BP is likely to have made 
possible a short-term spread of Abies sibirica in the area.

Shifts in the temperature index and moisture index curves point towards colder and slightly dryer conditions between 119.5 and 119 ky BP, suggesting another climatic oscillation. At that time the significance of Abies sibirica and Pinus sibirica decreased in the region around the lake, brought about a retreat of Siberian pine-spruce taiga, and associated spread of birch forest-steppe and steppe communities. The climate becomes progressively colder after 119 ky BP.

\subsubsection{Interglacial/glacial high-amplitude climate variation}

From about $117.5 \mathrm{ky} \mathrm{BP}$, the climate indices shift towards low temperatures and increased aridity, resulting in the complete disappearance of the taiga communities. In these extreme continental climatic conditions, only steppe communities could develop and, to some small degree, in habitats with more available moisture, communities of subalpine shrubs (Alnus fruticosa) as well as shrub willows and dwarf birches.

\subsection{Climatic signals inferred from the Baikal pollen record and their correlations with other local and regional data}

Climatic oscillations within the Last Interglacial, distinguished on the basis of changes of the pollen spectra, correlate with phases of low production of biogenic silica and decreased total organic carbon in the sediments of other drill cores from Lake Baikal.

The decline in the pollen values of Abies and Picea during the oldest climatic oscillation (126-125.5 ky BP), the cool and moderately dry, coincides with the period of a noticeable decrease in biogenic silica and in total organic carbon contents in the sediments of core BDP-96-2, dated at 126-125 ky BP (Prokopenko et al., 2002).

In the older part of the Eemian in some European pollen records there are signals of a small deterioration of climatic conditions. In Lac du Bouchet (France) a small increase in NAP (Thouveny et al., 1994 ) is dated at $126.5-126$ BP. Somewhat earlier, i.e. 127.3 ky BP, climatic changes expressed in the expansion of deciduous oak, also took place in north-west Greece (Tzedakis et al., 2003). The climate of southern Europe, which was moist up to this point, became warmer and drier in the period between 126.8 and $125.7 \mathrm{ky}$ BP.

Changes in vegetation in the Baikal region during the next climatic oscillation (121.5-120 ky BP) take place in the same period as a very clear fall in biogenic silica and total organic carbon in core BDP96-2 from the Academician Ridge in the Northern Basin of Lake Baikal. Simultaneously a clear fall in diatom concentrations is recorded in this core, as well as in the core VER-93/2pc2 (Karabanov et al., 2000; Khursevich et al., 2001; Prokopenko et al., 2002). The diatom record from the CON01-603-2 core provides yet other evidence of the existence of this lowamplitude cold event at ca. $120 \mathrm{ky}$ BP. This is expressed by a drop in productivity as indicated by changing biovolume accumulation rates (Rioual et al., 2005-this volume).

The cold oscillation recorded in the Baikal sediments perhaps correlates with the much discussed European Mid-Eemian cooling which made its mark in Lac du Bouchet between 120.5-119.5 ky BP in the expansion of open subalpine vegetation under the influence of colder and wetter climatic conditions (Thouveny et al., 1994). The changes in vegetation between 123.6 and $120.3 \mathrm{ky} \mathrm{BP}$ in north-western Greece (Tzedakis et al., 2003) also point to cooler but more moist climatic conditions. In the pollen record, this was expressed by a decline in Mediterranean elements and an increase in Carpinus betulus pollen (op. cit.). In contrast with the European oscillation, however, in south Siberia this was a dry phase.

Correlation of the youngest climatic oscillation with phases of lowered paleoproductivity in Lake Baikal is more problematic. The small-scale changes in Siberian pine-spruce forest composition between 119.5 and 119 ky BP precede the slight decline in biogenic silica in the sediments of core BDP-98, dated at about 119-117.5 ky BP (Prokopenko et al., 2002).

In the light of existing data, the changes in European vegetation do not suggest the presence of climatic disturbances in the 119.5-119 ky BP period. Fluctuations in the development of vegetation in north-west Greece, expressed by an increase in open vegetation pollen taxa percentages, take place within the period between 118.2 and $117.7 \mathrm{ky}$ BP (Tzedakis et al., 2003), i.e. much later than the vegetation changes in the Lake Baikal region. 


\section{Conclusions}

The pollen record presented from the sediments of the north basin of Lake Baikal spans the late glacial of the Taz Glaciation, the complete interglacial succession, and the beginning of the first stadial of the Zyryanka Glaciation. According to pollen data, the Kazantsevo Interglacial in the north Baikal region lasted from 128 to $117.4 \mathrm{ky} \mathrm{BP}$, i.e. about $10.6 \mathrm{ky}$.

The vegetation changes in the north Baikal region provide the evidence for some instability in the climate system during the Last Interglacial in southern Siberia. The development of forest communities was disturbed as a result of three short-term climatic oscillations. The earliest dry and cool oscillation (126-125.5 ky BP), led to a reduction in the occurrence of fir in taiga communities. The next one, (121.5-120 ky BP), took place during the maximum development of pine-larch taiga and was characterised by a somewhat drier and colder climate. During the youngest oscillation (119.5-119 ky BP) started the general trend of climatic change towards cooling. All these climatic phases coincide with reduced bioproductivity in the lake recorded in other Baikal cores. The two older climatic oscillations from south Siberia (126-125.5 and 121.5-120 ky BP) seem to be roughly contemporaneous with climatic fluctuations recorded in some European localities. This suggests the existence of connections between the climatic changes in Europe and south Siberia during the Last Interglacial. However it requires stronger chronological framework.

Climatic changes inferred from vegetation history indicate the beginning of the Last Interglacial in south Siberia was rather warm and relatively wet in opposite to West Siberia and Europe where this part of the Last Interglacial was warm and dry.

To gain a better understanding of the vegetation and climatic changes during the Last Interglacial in south Siberia, further studies of interglacial sediments from the Central and Southern Basins of Lake Baikal as well as from neighbouring areas are of essential importance.

\section{Acknowledgements}

The authors wish to thank Dr. Pavel Tarasov and Dr. Hedi Oberhaensli (both from Potsdam) for constructive critics on the manuscript. Our thanks are also due to Dr. Anson Mackay (London) for valuable comments and linguistic correction.

The studies were performed as part of the EU project EVK2-CT-2000-00057 “CONTINENT: Highresolution continental palaeoclimate record in Lake Baikal: A key-site for Eurasia teleconnections to the North Atlantic Ocean and monsoonal system." W.G. also thanks the State Committee for Scientific Research (KBN) for financial support.

\section{References}

Arkhipov, S.A., Volkova, V.S., 1994. Geological history, Pleistocene landscapes and climate in West Siberia. Russian Academy of Sciences, Siberian Branch, United Institute of Geology, Geophysics and Mineralogy, Transaction, Issue 823, Novosibirsk (in Russian).

Belov, A.V. (Ed.), 1972. Map of Vegetation of the South of East Siberia. AN SSSR, Main Agency of Geodesy and Cartography at the Council of Ministers of the USSR, Moscow (in Russian).

Belova, V.A., 1985. Vegetation and Climate of the Late Cenozoic in Southern East Siberia. Nauka, Novosibirsk, 160 pp. (in Russian).

Bezrukova, E.V., Letunova, P.P., 2001. A high-resolution record of east Siberian paleoclimates during the Early and Middle Pleistocene by palynological studies of Baikal sediments from the deep borehole BDP-96-1. Geol. Geofiz. 42, 98-107 (in Russian).

Bezrukova, E.V., Kulagina, N.V., Letunova, P.P., Shestakova, O.N., 1999. Climate and vegetation changes in the Bakal region for the last $5 \mathrm{Ma}$ (according to palynological data on the Baikal sediments). Russ. Geol. Geophys. 40, 722-731.

Channell, J.E.T., 1999. Geomagnetic paleointensity and directional secular variation at Ocean Drilling Program (ODP) site 984 (Bjorn Drift) since $500 \mathrm{ka}$ : comparison with ODP site 983 (Gardar drift). J. Geophys. Res. B: Solid Earth 104, 22937-22951.

Charlet, F., Fagel, N., De Batist, M., Hauregard, F., Minnebo, B., Meischner, D., SONIC Team, 2005. Sedimentary dynamics on isolated highs in Lake Baikal: evidence from detailed highresolution geophysical data and sediment cores. Glob. Planet. Change 46, 125-144 (this volume)

Cheddadi, R., Mamakowa, K., Guiot, J., de Beaulieu, J.-L., Reille, M., Andrieu, V., Granoszewski, W., Peyron, O., 1998. Was the climate of the Eemian stable? A quantitative climate reconstruction from seven European pollen records. Palaeogeogr. Palaeoclimatol. Palaeoecol. 143, 73-85.

Chlachula, J., 2001. Pleistocene climate change, natural environments and palaeolithic occupation of the Angara-Baikal area, east Central Siberia. Quat. Int. 80-81, 69-92.

Cwynar, L.C., Burden, E., McAndrews, J.H., 1979. An inexpensive sieving method for concentrating pollen and spores from finegrained sediments. Can. J. Earth Sci. 16, 1115-1120. 
de Beaulieu, J.-L., Reille, M., 1992. Long Pleistocene pollen sequences from the Velay Plateau (Massif Central, France): I. Ribains maar. Veg. Hist. Archaeobot. 1, 233-242.

Demory, F., Nowaczyk, N.R., Witt, A., Oberhänsli, H., 2005. Highresolution magnetostratigraphy of late Quaternary sediments from Lake Baikal, Siberia: timing of intracontinetal paleoclimatic response. Glob. Planet. Change 46, 167-186 (this volume).

Faegri, K., Iversen, J., 1989. Textbook of Pollen Analysis. John Wiley and Sons, Chichester.

Field, M.H., Huntley, B., Müller, H., 1994. Eemian climate fluctuations observed in a European pollen record. Nature 371, 779-783.

Grichuk, V.P., 1984. Late Pleistocene vegetation history. In: Velichko, A.A., Wright, H., Barnosky, K.W. (Eds.), Late Quaternary environments of the Soviet Union. University of Minnesota Press, Minneapolis, pp. 155-178.

Grimm, E.C., 1987. Coniss: a Fortran 77 program for stratigraphically constrained cluster analysis by the method of incremental sum of squares. Comput. Geosci. 13, 13-35.

GRIP members, 1993. Climate instability during the last interglacial period recorded in the GRIP ice core. Nature 364, 203-207.

Hutchinson, D.R., Golmshtok, A.J., Zonenshain, L.P., Moore, T.C., Scholz, C.A., Klitgord, K.D., 1992. Depositional and tectonic framework of the rift basins of Lake Baikal from multichannel seismic data. Geology 20, 589-592.

Karabanov, E.B., Prokopenko, A.A., Williams, D.F., Khursevich, G.K., 2000. Evidence for mid-Eemian cooling in continental climatic record from Lake Baikal. J. Paleolimnol. 23, 365-371.

Khursevich, G.K., Karabanov, E.B., Prokopenko, A.A., Williams, D.F., Kuzmin, M.I., Fedenya, S.A., Gvozdkov, A.A., 2001. Insolation regime in Siberia as a major factor controlling diatom production in Lake Baikal during the past 800,000 years. Quat. Int. $80-81,47-58$.

Klotz, S., Guiot, J., Mosbrugger, V., 2003. Continental European Eemian and early Würmian climate evolution: comparing signals using different quantitative reconstruction approaches based on pollen. Glob. Planet. Change 36, 277-294.

Kühl, N., Litt, T., 2003. Quantitative time series reconstruction of Eemian temperature at three European sites using pollen data. Veg. Hist. Archaeobot. 12, 205-214.

Menke, B., Tynni, R., 1984. Das Eeminterglazial und das Weichselfrühglazial von Rederstall/Dittmarschen und ihre Bedeutung für die mitteleuropäische Jungpleistozängliederung. Geol. Jahrb., Reihe A 76, 2-120.

Müller, H., 1974. Pollenanalytische Untersuchungen und Jahresschichtenzählungen an der eemzeitlichen Kieselgur von Bispingen/Luhe. Geol. Jahrb., Reihe A 21, 149-169.

Peshkova, G.A., 1985. Vegetation of Siberia (Predbaikal'e and Zabaikal'e). Nauka, Novosibirisk (in Russian).
Prokopenko, A.A., Karabanov, E.B., Williams, D.F., Khursevich, G.K., 2002. The stability and the abrupt ending of the Last Interglaciation in southeastern Siberia. Quat. Res. 58, 56-59.

Rioual, P., Mackay, A.W., Demory, F., Oberhaensli, H., 2005. A diatom record of centennial resolution for the Kazantsevo Interglacial stage in Lake Baikal (Siberia). Glob. Planet. Change 46, 199-219 (this volume).

Stockmarr, J., 1971. Tablets with spores used in absolute pollen analysis. Pollen Spores 13, 615-621.

Tarasov, P.E., Webb, T., Andreev, A.A., Afanas'eva, N.B., Berezina, N.A., Bezusko, L.G., Blyakharchuk, T.A., Bolikhovskaya, N.S., Cheddadi, R., Chernavskaya, M.M., Chernova, G.M., Dorofeyuk, N.I., Dirksen, V.G., Elina, G.A., Filimonova, L.V., Glebov, F.Z., Guiot, J., Gunova, V.S., Harrison, S.P., Jolly, D., Khomutova, V.I., Kvavadze, E.V., Osipova, I.R., Panova, N.K., Prentice, I.C., Saarse, L., Sevastyanov, D.V., Volkova, V.S., Zernitskaya, V.P., 1998. Present-day and mid-Holocene biomes reconstructed from pollen and plant macrofossil data from the Former Soviet Union and Mongolia. J. Biogeogr. 25, 1029-1054.

Tarasov, P.E., Volkova, V.S., Webb, T., Guiot, J., Andreev, A.A., Bezusko, L.G., Bezusko, T.V., Bykova, G.V., Dorofeyuk, N.I., Kvavadze, B.V., Osipova, I.M., Panova, N.K., Sevastyanov, D.V., 2000. Last glacial maximum biomes reconstructed from pollen and plant macrofossil data from northern Eurasia. J. Biogeogr. 27, 609-620.

Thouveny, N., de Beaulieu, J.-L., Bonifay, E., Creer, K.M., Guiot, J., Icole, M., Johnsen, S., Jouzel, J., Reille, M., Williams, T., Williamson, D., 1994. Climate variations in Europe over the past $140 \mathrm{ky}$ deduced from rock magnetism. Nature 371, 503-506.

Turner, C., 2000. The Eemian Interglacial in the North European plain and adjacent areas. Geol. Mijnb. 79, 217-231.

Turner, C., 2002. Problem of the duration of the Eemian Interglacial in Europe north of the Alps. Quat. Res. 58, 45-48.

Turner, C., West, R.G., 1968. The subdivision and zonation of interglacial periods. Eiszeitalt. Ggw. 19, 93-101.

Tyulina, L.N., 1976. Moist Near-Baikal Type of Vegetation Zonation. Nauka, Novosibirsk, 320 pp. (in Russian).

Tzedakis, P.C., Frogley, M.R., Heaton, T.H.E., 2002. Duration of Last Interglacial conditions in Northwestern Greece. Quat. Res. $58,53-55$.

Tzedakis, P.C., Frogley, M.R., Heaton, T.H.E., 2003. Last Interglacial conditions in southern Europe: evidence from Ioannina, northwest Greece. Glob. Planet. Change 36, 157-170.

Volkova, V.S., Bakhareva, V.A., 1995. Climate of optimum Late Quaternary (Kazantsevo) interglacial in West Siberia and climate prognosis for the nearest future. Geol. Geofiz. 36 (11), 23-33 (in Russian). 